\title{
SOCIAL REPRESENTATIONS OF SUCCESS IN DIFFERENT PROFESSIONAL STRATA
}

\author{
IBolya VARI-SZILAGYI - ZsUZSA SOLYMosI
}

\begin{abstract}
In societies heading for modernization, culture- and stratum-specific cognitive representations of social success also undergo change, but it is by no means indifferent to the process of development how they change. Nor is Hungary an exception, where after the changes of the early 1990s the findings of research which give an insight into the images of social and personal success among professionals who play a decisive role in modernization might be of special interest, and perhaps utility. These images are indicators of status as well as motivations in the given process of modernization. The investigation described in this paper used cognitive social psychology to explore the social representations of success among would-be and practicing members from three professional fields (agricultural engineers, architects and economists) who had and still have varying chances of success after the political changes. The present study only enlarges upon a part of the complex questionnaire survey, specifically the alleged factors and traits (causal attributes) that underlie the success of a) successful persons that respondents' personally know, and b) generalized Hungarian successful persons, together with the factors that structure the social representations of success, as well as significant differences in these by gender, professional field and generation. The most conspicuous of our findings relates to negative emotional perceptions about the generalized successful Hungarian man, especially in the subsample of students. Known successful people are almost exclusively male and come from the world of business, which is a remarkable sign of the survival of earlier beliefs, even if otherwise no comprehensive difference was detected between the genders. Neither was a difference specific to the field of specialisation identified, in contrast to generation-specific divergences (particularly concerning the more complex approach of earning professionals to achievement, staying well-informed and communicative skills).
\end{abstract}

KEYWORDS: success, motivation, values, gender

1 Ibolya Vari-Szilagyi is an advisory social psychologist at the Insitute of Neuroscience and Psychology at the Hungarian Academy of Sciences (HAS), Budapest; e-mail: jogazo@t-online.hu; Zsuzsa Solymosi is a sociologist and advisory social psychologist at ELTE, TATK Budapest. This research was carried out using a grant from the Hungarian Scientific Research Fund. The title of the four-year project was "Models, ideologies and values of success." Other researchers involved in the project include the sociologists Anna Hamar and Ildikó Hrubos. Special thanks are due to mathematician Mihály Sipos for statistically processing the research data. Details of the calculations are available from the authors upon request. 


\section{INTRODUCTION}

Success and failure are among those social phenomena whose complexity is hard to decipher, yet by affecting people deeply they strongly challenge them to search for interpretations. Since all members of society are involved - everyone wishes to be successful -, people often fall into the trap of employing simplistic explanations that reduce success or failure to a single factor (e.g. luck or hard work), and the more so since these patterns of interpretation are already present as images of social climbing and are socially inherited and embedded in the relevant culture. Such explanations are usually spontaneously accepted, unless the challenge of certain social situations and new life experiences forces one to do otherwise. Societies modernized to various degrees have different images of success which differ in their content and intensity (e.g. in terms of effectiveness and power). As culture- and stratum-specific social representations of success, they influence behavior of individuals and groups (Merton, 1963:134-135; 166-170).

Relevant literature has revealed that in modern industrial societies, and during the age of modernization, more defined lay concepts and ideologies about success have appeared, within which the relationship between the goals of success and the means of achieving them may be essential indicators of a society's (healthy, sick, or "anomalous") development (Merton, 1963:136-137). How many and which of the explored components of the concepts of success are of universal validity, and which only apply to specific societies, strata or groups is an open question, and as such, can be subject to empirical investigation.

Although success and failure were research topics for psychology as early as the thirties, it was only failure which became a classical and empirically widely studied subject; the empirical investigation of success lagging behind, or being left to sociology. The theme of success came to the fore in the 1920 s and 1930s, particularly in German economic sociology, for reasons not to be enlarged upon here (Mannheim, 1930; Ichheiser, 1930;1933). In accordance with this interest, in psychology Lewin and Hoppe introduced the concept of level of aspiration (Hoppe, 1930; Lewin, 1933/44; 1936), the authors being the first to examine actual performance in a laboratory setting. Around that time, G. Ichheiser not only investigated the everyday meanings of success, but created a coherent conceptual frame for studying it. This represented a major contribution, as the researcher selected and integrated the phenomenological, sociological and psychological variables of success 
with great sensitivity. ${ }^{2}$ Mannheim was the first to acknowledge Ichheiser's insightful achievements. The authors discovered the easily committed errors and misdirections in research into success at the same time. The axiom they proposed has it that success should be both theoretically and empirically separated from achievement, since the latter is a tangible result, objectified in a specific field (Sachgebiet), while success may be achieved in the area of social relations (Mannheim, 1930). Social success and recognition, and positional advance in social space was regarded as the primary meaning and main plane for the structuration of success. This was confirmed by early empirical studies of success, as well as those of the 1960s (Mannheim, 1930; Ichheiser, 1033; Merton, 1957; Katz, 1964). As Ichheiser stated, "in contrast to the dimension of achievement rooted in the professional area, the dimension of success must be accepted as a specifically social dimension. Its main distinguishing feature is that it stretches between 'high' and 'low' (as the social living space is hierarchically structured)" (Ichheiser, 1933:101). The sphere of achievement may be differentiated from this, since the result of an action is in instrumental relationship with the sphere of success, which is precisely why the two spheres are so easily mixed up or merged (causing serious misunderstandings), although the interrelation between the two spheres is the actual subject of research. ${ }^{3}$ Ichheiser warned that "any reasoning about the phenomenon of success that fails to acknowledge or see clearly that an indispensable and decisive condition for the experience of success is social self-assertion, will be mistaken, so both the 'attainment of the set goal' and the 'realization of achievement' will assume the psychological character of failure where the component of social self-realization is missing or is evaluated negatively" (Ichheiser, 1933:105).

It is another indicator of the complexity of the theme of success that an individual's actual experience of success often considerably differs from both the dominant

2 Ichheiser identified the following customary meanings of success: a) success as the attainment of a set goal, b) as the realization of an achievement, c) as getting along in the social space, d) as "derailed" interpretations of success (identifying success either with the consequences or with the conditions; e.g. calling myself a success if I am satisfied with myself), e) other: including some vague and inconsistent misinterpretations in smaller proportions. In his investigation of success in the social sphere in 1930, success was represented in the greatest proportions (31\%) among Viennese teenagers of 14-16 years of age. It is noteworthy that although in the preliminary investigation the dominant meaning of success was identified with social recognition, in the present study "inner satisfaction" was the most frequently identified meaning of success. Social recognition was pushed far into the background among all the concepts of success, as revealed by the rankings of characteristics, with no significant difference between the two subsamples and the two images of successful people.

3 Ichheiser opined that the specifically social dimension of success is different and as such it can be differentiated from the sphere of achievement in which the outcome of an action cannot be regarded as an achievement unless it was produced by deliberate effort, and moreover, was realized in some socially acknowledged area (Ichheiser, 1933:99; 101-105). 
concept of social success, and from the person's actual performance. The image of success as motivating individual activity depends not only on the person's abilities and efforts, but on the social space they perceive and recognize, and eventually these together form the frame of reference for a person's level of aspiration (for Ichheiser's relevant ideas, see in more detail: Vari-Szilagyi, 1987; 1990; 2002).

The concept of success itself has several and different meanings, as the contents of the phenomenon it signifies may also differ depending on social value preferences and ideologies about success, as well as on the value preferences and experiences of individuals. The point here is not merely that in various fields of social activities the prototypes of successes are different (i.e. that the criteria and symbols of success are different in business, art, scholarship, etc.), but that success itself may have varying meanings for diverse cultures, strata, groups and individuals. It may be identical with financial success, may denote social ascent, higher status and social recognition related or not related to the former, a secure job, or other things. Which of the above meanings of success becomes predominant in a certain period of a society is symptomatic, revealing how the value contents of the images and goals of success are evaluated in a culture-specific system of values. For example, it was symptomatic of American society as described by Merton, as well as of its cult of success, to identify success with financial enrichment and the attainment of the social status that it entailed. It is not the attainment of monetary wealth that is specifically American, but the impulse to acquire it; the ambition to rise and wasteful consumption have become culturally prescribed goals and expectations in American society (Merton, 1963:136-137). ${ }^{4}$ In his research in Australia, Katz found that financial success may be the measure of success, without the aspiration of rising in the social hierarchy (Katz, 1964).

Since these lay or 'naive psychological' theories are created from beliefs of collective origin under the constraints of everyday life in an effort to economize and spontaneously balance cognitive processes, their ideological nature (derived from false consciousness) remains veiled. Yet a closer look at either the dominant success cult of a society or at the divergent images of success adopted by various strata or groups reveals the ideology of success hidden behind them. In Ichheiser's interpretation, the view that one must believe in one's ability to attain higher social status via personal effort, competence and merit, while the different degrees of accessibility for various classes or strata to these statuses or higher positions remain obscure, is an ideology. One of the manifestations of the American ideology

\footnotetext{
4 While Merton was able to outline a relatively coherent picture on the basis of his research into the American cult of success in the 1940s in which the indicators of the conceptual, action-related and emotional-empirical dimensions all pointed in the same direction (at least in the 1950s and 1960s), there are several other social establishments or countries in which achievement and social success are far removed from one another, although this possibility is little present in the rhetoric. Many signs indicate that the Vietnam war and the student movements of 1968 generated a rift in American society regarding the criteria of success.
} 
of success claiming that "intelligence, hence work and financial success, are the outcome of education" would be received skeptically today in the United States, too (Malcolm, 1938:29, quoting Merton, 1963:135). Similarly to Merton, Forgas, Morris and Furnham (1982), as well as Csepeli and his co-authors (1992) describe fatalist views blaming fate alone for social success, wealth or poverty, and those who attribute success and failure solely to personal qualities, as ideologies (Merton, 1963:168; Forgas et al. 1982; Csepeli et al., 1992:22).

Early research into success called attention to the attributional tendencies hidden in the perception and dominant ideologies of success. Ichheiser analyzed in detail how a successful person is attributed external and internal factors/characteristics in relation to his intended activities, and how the accessibility of success is perceived (how, for example, unemployment is regarded by outside observers as a negative personality trait (Ichheiser, 1930; 1970)) Heider, considered to be the father of attributional theory, borrowed several relevant ideas and examples from Ichheiser (Heider, 1958:62,87,96). Subsequent research has thrown light onto the stratum-specific reception of the dominant ideologies and values of success. They have demonstrated that the pattern of success directed at the attainment of higher social status and concomitant wealth especially reflects the value preferences of the middle classes (Hyman, 1953; Katz, 1964).

Two central features of social representations apply to each of the concepts of success: the first is that they are not only individual, but also stratum- and culture-specific mental structures of collective origin, and the second is that they are "shared knowledge", and as such, they participate in influencing subsequent public thought and behavior (Weber, M.,1925; Moscovici, 1961; 1963).

The actuality of research into the social representation of success has been enhanced in East-Central European countries through the processes of learning how to democratize and privatize after the change of the political system. Since in all Hungarian investigations concerning professionals and values carried out in the 1970s and 1980s financial motivation was shyly relegated to the background, if mentioned at all in responses, it is intriguing to see how the spectacular transformation of the macro-environment in this direction, and how the shocking manifestations of economic and financial polarization in society have influenced the role of financial and achievement motivation in the values and concepts of success. ${ }^{5}$

\footnotetext{
5 In the latter half of the 1980s researchers were able to detect the emerging signs of a blurred image of the future. This involved growing levels of uncertainty and fear in relation to the realization of professional ambitions and work, a value crisis and value relativization, as well as abstaining from management and public appearances among future intellectuals, with the exception of would-be agricultural engineers. Partly as a reaction to the fact that owing to a reluctance to take on political roles a considerable gap had opened up between achievement and social success, corruption and behaviour-violating rules and norms became general. It was then rightly asked what beliefs and concepts of success do individuals have to face this new situation. How are they prepared to meet a more open future, to utilize a wider space of action?
} 


\section{A FEW FINDINGS FROM EMPIRICAL RESEARCH}

\section{Targets and hypotheses of the research}

The question to be answered by the investigation, as described below, was what images and ideologies of success are predominant today in the Hungarian intellectual professional strata which play a salient role in modernization. Valid information was to be gained about:

- what attributional tendencies are reflected in Hungarian images of success;

- what share monetary success and affluence has in these images, and what role professional achievement plays in them;

- what gender-, profession- and generation-specific features of these images of success can be established with probability.

Here, only the results of the elaboration of the answers to a few questions notably, information about the social perception of successful personally known and generalized successful Hungarian persons - are presented. ${ }^{6}$

The investigation being exploratory, the following preliminary hypotheses were formulated:

- significant differences are expected to be found between intellectual professional strata with considerably different access to success, and between subsamples of university students and graduates who represent the age differences in these layers;

- men and women will differ in terms of their evaluation of certain potential success factors and characteristics;

- in the value order of respondents, financial success will be placed higher on the list than in earlier surveys;

- in the given social space, factors and properties which reflect achievement will be both positively and negatively evaluated;

- personally known successful people will be more idealized than the generalized Hungarian successful individual.

\footnotetext{
6 Our investigation covered a far broader area both in regard to content and applied methods than described in the present study. The questionnaire also gathered information on successful individuals as represented in the mass media, on successful men considered to be ideal, on near and distant goals (images of the future), on the degree of responsibility individuals assume in the realization of their plans, on the presumed influence of external circumstances, on the repondents' own successfulness and optimism, on their life views reflecting their values, and on entrepreneurial attitudes. The questionnaire survey was supplemented by in-depth interviews with approximately one-third of the studied sample.
} 


\section{Method, sample, process of investigation}

The main tool for exploring the images of success was an extensive self-administered questionnaire survey that ensured anonymity, supplemented by interviews with one-third of the sample. The survey instrument was a complex questionnaire that the authors devised and tested in two pilot studies in 1991 and 1992, then finalized. Cognitive social psychology theory was applied in its construction.?

The overwhelming majority of questions were closed in nature (except for those which asked the respondent to recall his/her experience of success/failure).

The results explicated below touch on the responses to the following questions (and represent only some components of the entire survey):

- who the personally known successful person is (gender, line of work, connection to respondent);

- what factors can the person's successfulness be attributed to (ranked on a 4-point scale using 14 factors);

- what traits are they characterized by (evaluated with semantic differential on a 7-point scale of pairs of antithetical characteristics);

- what is a generalized successful Hungarian person like today, assessed with the above tools.

Potential success factors and likely characteristics of successful people were chosen and finalized on the basis of the experiences of the pilot studies, with care being taken that both internal (related to an individual's abilities and efforts) and external factors (pertaining to conditions beyond the person's control, or to his/ her outwards looks) be equally represented.

The sample included three types of intellectuals - agricultural engineers, economists and architects - considered to be widely differing in their chances of success, and two sub-samples which included final year university students and graduates aged between 30 and 40 with several years of work experience behind them. To elaborate on the questionnaire responses we used standard procedures: the significant differences between judgments about two objects were revealed by the results of one-tail t-tests, while certain clusters of beliefs and

\footnotetext{
7 The questionnaire was compiled so that the respondent could both react as an observer and as an actor. When their opinions were solicited about the factors and characteristics that contribute to the success of a successful person (both personally known and average contemporary successes), respondents could concentrate their attention on success (or failure), providing in the meantime relevant information and interpretations which were elaborated on and applied inevitably from the viewpoint of the observer. In other sections of the questionnaire -not touched upon in this paper for example, when respondents were asked about their own experiences of success and failure, the degree of their success, etc., or about the primary meaning of success as they interpret it, they could answer in the role of actors.
} 
opinions were examined using factor analysis. The independent variables in the one-way ANOVA included gender, professional field, and personality traits based on self-reporting.

\section{PRESENTATION OF RESULTS}

\section{Who is regarded as successful person today?}

The first block of questions referred to 'personally known successful persons'. In both subsamples, 90 and $87 \%$ respectively stated that men were those who were truly successful, so the concept of success is associated with men. Women also specified males, though they mentioned women in slightly higher proportions than male respondents, with economists being most liable to select a woman. Most of those questioned picked successful actors in the sphere of the economy, which may hint at the growth in the role of material enrichment in images of success. At the same time, there are some considerably marked differences between students and graduates in this regard: less than $50 \%$ of university students mentioned the economic sphere and a relatively high proportion of them mentioned scholarship, while nearly every third such respondent named a well-known successful person from some other field (sports, pop music, academic competition, etc.). In contrast, $65 \%$ of graduates named a person in the economic sphere, all other spheres receiving an insignificant number of votes (below $10 \%$ ). The only exception was sports, in which field nearly every fifth respondent named a successful person. The divergence between the two structures of choice indicates that university students are less familiar with different circles of individuals than working intellectuals owing to their age and position as students.

Similarly, many points of difference were identified between the two subsamples in terms of their relationship with the personally known successful person. Undergraduates' answers were dominated by close or distant kinship relations (33 $\%)$; the same amounted to $17 \%$ among working professionals. In both subsamples immediate relatives were rarely mentioned (10 and $5 \%$, resp.), while distant relatives were named in $23 \%$ of cases by students and only $5 \%$ by professionals. A significant difference was found with naming friends: a mere fifth of students pride themselves on having successful friends, in comparison to a third of university graduates. The rest of the respondents (amounting to a not negligible $50 \%$ or so), could only name successful persons among their closer or distant acquaintances.

What lends special interest to our results is that, as earlier authors also pointed out (Merton, 1958; Katz, 1964), the choice of the personally known successful person is usually an indicator of the reference person or group. It is to be noted, 
however, that those investigations were carried out in more consolidated societies with clearer conditions for success, where tested and tried success ideologies were the models for selection.

\section{Social perception of success factors}

Ranging in order of importance, the 14 internal and external factors potentially accountable for success reveal the ranking of causal attributions (Appendices No.1 and No.2, ranking of success factors for personally known and Hungarian successful persons in the two subsamples).

In the case of personally known successful persons some internal personal factors - invested 'hard work', 'decision-making ability', 'determined manner' and 'perseverance' - were regarded as being of paramount importance (with the addition of 'being well-informed' as an external factor) and external factors ('pleasant outward appearance', 'good luck' or 'chance', 'favorable financial circumstances') were listed last. Let us here call attention to the controversial and contextual meaning of 'being well-informed', to be discussed later.

The other set of questions referred to generally successful Hungarian people; to the generalized image entertained by the respondents in the modern Hungarian situation as concerns the factors and personal endowments of success. As Appendices 1 and 2 show, those who were asked put external factors in first place, ahead of internal ones. Topping the list were 'being well-informed', and 'having good connections', with the addition of the internal factors required for management ('decision-making ability', 'resolution of purpose', 'good faculty of speech'). 'Favorable financial standing', placed last in the case of known successful persons, rose to 7th place for the average Hungarian successful person. Undergraduates ascribed significantly lower importance to perseverance, hard work and outstanding achievements.

The appendices also reveal that no significant differences can be demonstrated between the two subsamples (university students and practicing professionals) in terms of their ranking of factors that create the success of either the personally known or the generalized successful Hungarian person. Attributional tendencies are similar: personally known successful people are more favorably perceived.

No significant difference could be pinpointed using t-tests in the students' evaluations of personally known and Hungarian successful persons as regards pleasant appearance, decision-making ability and insight into character. In the subsample of graduates who were already practicing their professions, the t-tests did not indicate significant differences in terms of the two images concerning likeable appearance, decision-making ability, determined manner, insight into 
character and good faculty of speech. It is a noteworthy difference in the images of success of the two subsamples that while graduates ascribed the same importance to 'outstanding achievement' in both cases, university students relegated this feature to the background in the case of the Hungarian successful person, compared to the personally known successful person, thereby distancing themselves from the performance of generally successful Hungarian people, so to speak. The meaning of some factors (first of all, 'being well-informed') seems to depend on context: coupled with internal factors it is rather positive, and with external factors it is rather negative in meaning, but this is not strictly so. Paired with managerial skills it also becomes a managerial virtue.

Characteristic differences according to professional sector appear in the far greater weight placed by agricultural experts on being well-informed, which is probably attributable to the crisis in the agrarian sector and the concomitant social uncertainty of agricultural engineers in the 1990s. Perseverance and achievement are ascribed salient importance by architects compared to the weak-medium ranking of others. As the interviews revealed, this opinion of architects is fed by the conviction that only persistence, continuous effort and successful or unsuccessful but regular participation in competitions promote one to the rank of a leading architect.

After the examination of the presumed significance of each potential success factor, we looked at the set of factors itself so as to identify what dimensions these factors represented.

For the personally known successful person, factor analysis of the components (potential factors) of success brought out three main factors responsible for the shaping of opinions in both subsamples: 'external factors', 'work' and 'communication'.

Regarding the generalized Hungarian successful person, opinions were again molded by three common factors: 'work', 'communication' and 'external factors'. (A more detailed earlier analysis is described in Váriné Szilágyi I.-Solymosi Zs.(eds.)(1999)). Each factor contributed over $10 \%$ of the total explanation, and combined they had a total explanatory power of $48 \%$ and $55 \%$, and 52 and $57 \%$, respectively. The factors were easy to categorize. ${ }^{8}$

\footnotetext{
8 It is important to understand well the role that each factor or characteristic-factor played in the shaping of the two different images of success. It is not the personally known or generalized Hungarian successful person that the factors are typical of (e.g. the fact that the 'external circumstance' factor has the greatest explanatory force for personally known successful persons does not mean that the named individuals really owe their success chiefly to circumstances described by this category). Besides showing the stable or unstable coincidence of certain circumstances or characteristics, the distinctly separated factors also reveal which are the dimensions of circumstances and properties in which the polarization and concurrence of judgments by the entire sample most strongly affect the overall picture of the subject of evaluation, and the entire opinion. From this perspective, both factors and individual circumstances or characteristics which were not mentioned might be highly informative (particularly those about which there is certainly a high degree of consensus, positive or negative).
} 
The next step was to establish correlations between these factors and other parameters which presumably influence opinions. It was supposed that, besides gender and the different professional sectors, certain personality variables such as inner- or outer-directedness (internal or external control), the degree of alleged successfulness and optimism - might also influence the presence and weight of a factor in the causal explanation of the success of known and generally Hungarian successful individuals. These variables were inferred from the elaboration of self-reported data indicated by use of the formalized scales in the questionnaire that referred to the respondent's own experience of success and failure.

Along these variables, subgroups of low-medium-high means were created and in the following the above group determinants were used as independent variables in the calculations needed to make comparisons. We were curious to see if in the groups that were distinguished (by gender, professional sphere, internal/external control, alleged successfulness, optimism) there were measurable differences as to the means of given factor weights. We carried out a one-way analysis of variance for each of the mentioned variables.

In the subgroup of students, gender and professional field proved to have contributory effect on opinions about personally known successful persons, in that males and future agrarian professionals ascribed greater weight to 'external factors' and less to the 'work' factor in the evaluation of successfulness, while female students and future architects held opposing opinions. These differences, however, did not characterize the groups under examination in terms of explaining the success of the average Hungarian 'big shot'.

In the subgroup of graduates, opinions were more homogeneous in explaining the success of both kinds of successful person: neither gender-specific nor professional area-specific differences were detected. In contrast, the inner/ outer directedness of the respondents (internal/ external control of behavior) had a characteristic influence on their opinions. There was significant consistency inasmuch as groups with lower internal control evaluated 'external factors' higher and deprecated the role of 'work factor' as possible causes for the success of individuals, while higher internal control was typically coupled with higher values for the 'work-factor' and less for 'external factors'.

\section{The social perception of the characteristic traits of successful people}

Further questions inquired into how the respondents assess and evaluate the successful person embedded in the two contexts. What features do they deem 
to be characteristic of them? This characterization was conducted by asking respondents to rank 25 pairs of opposing characteristics on a 7-point scale. ${ }^{9}$

The typical features topping the list of characteristics of the Hungarian and personally known successful persons (see Appendices No.3 and No.4) represented the dimensions of activity and power, and at first sight, the two rankings seem more or less the same. When taking a closer look, however, one finds that the two are differently appraised, corresponding to the tendency noted previously (notably, to slightly burnish the personally known successful person).

According to the ranking of characteristics, personally known successful person are active, self-reliant, self-assured, ambitious, determined and energetic, while risk-taking, generosity, adaptability, selflessness, etc. are far less characteristic. The generalized Hungarian successful person was chiefly characterized by features belonging to the dimensions of activity and power, but noteworthy differences were explored by a comparison of the characteristic means through a one-tail t-test.

There were no significant differences between the two successful persons in the pairs cheerful-sad, positive-negative, demanding-undemanding, well-known - not-well-known, sparing-squandering, optimistic-pessimistic, self-reliant lacking self-reliance, generous-petty-minded (a mere 8 pairs out of the 25).

What is conspicuous is that successful Hungarian individuals were ascribed characteristics representing the dimension of activity and power, or those required by leadership, whereas personally known success stories were assigned traits representing the dimension of appreciation, especially those important in evaluating interpersonal relations. On the whole, personally known successful people are deemed more sympathetic and likeable.

It needs separate mention that while in the preliminary investigations of 1991 and 1992 'being acknowledged' was the leading success criterion (i.e. was mentioned in greatest proportions) and so was expected to have a distinguished place in the ranking of features characterizing successful people, it did not play a significant role either in the ranking of features or in the comparison of the two images of success.

The data collected about on the characteristic traits of the two successful persons were again elaborated using factoral analysis.

Three factors of identical nature and name crystallized out from the factor analysis in both subsamples. The strongest explanatory force was attributed to the positive-evaluation factor (or 'human'-factor, as appraised by its content) by

9 The 25 pairs of properties were selected on the basis of the preliminary study. The dimension of activity was represented by the following parameters: active, ambitious, determined, flexible, quick, risk-taking, adaptive. The dimension of power was represented by: self-reliant, self-assured, energetic, powerful and independent. All the rest belonged to the dimension of evaluation. 
university students in the case of the personally known and the general Hungarian successful person alike (19\% and 23\%, resp.), followed by the factors resolve and activity-power, and optimism. Among professionals, the greatest explanatory power (22\%-22\%) was also ascribed to the positive evaluation factor, but a striking feature of the related findings is that among the characteristic traits belonging to determination was included risk-taking.

As for the characterization of the Hungarian successful person, three factors were again salient. This finding demonstrates some shift of emphasis in professionals' images of both kinds of successful person. All in all, these factors accounted for $37 \%$ and $47 \%$, resp., of the success of the personally known successful person, and 49 and 44\%, resp., of that of the Hungarian successful person.

Next, we investigated whether the groups formed along the specific variables we deemed important differed significantly in terms of the characteristics-factors of the above two pictures. For this purpose we carried out one-way ANOVA for each variable. Only gender, professional field and internal control proved to typically influence the factors: Women appraised the 'work'-factor to be of greater weight, while men represented the 'communication' factor more heavily. That there was hardly any significant deviance specific to professional field (if there was any, it was in the 'communication'-factor or in the 'self-reliance' factor, not discussed here, which indicates that significant differences exist between agricultural professionals and architects) that needs further explanation.

\section{DISCUSSION OF THE RESULTS}

In any phase of social transformation it plays a considerable role what image of success is adopted by the would-be and already practicing members of professional strata who are assigned, in theory, a great role in modernization, and who are now actors, then observers of events. The social representation of success, of a person of success, not only has roots in the past, but - from the perspective of constructing reality - also has consequences in the future.

Some of our preliminary hypotheses were not verified: no profession-specific differences were identified in the whole of the two images of success, except for the divergent representation of some individual factors of success or characteristics relevant to individual professions.

No overall gender-specific difference was exposed: irrespective of gender, personally known successful people were almost always male. In terms of the standard deviation of individual images of success, a one-way analysis of variance with factor points revealed significant differences: women proved more liable to idealize the personally known successful person, especially in the dimensions of 
'work' and 'determination'. These scattered differences, however, did not coalesce into clearly interpretable, gender-specific psychological patterns.

The only indication of a more explicit acceptance of striving for financial success was the fact that personally known successful people were chosen from the business sphere in the greatest proportions.

Outstanding achievement, a leading value in the survey of the 1980s, especially among future agricultural engineers and architects, was demoted in the ranking of factors and features considered to structure success.

The results revealed the generational differences between the two subsamples remarkably well: in regard to both the professional field, the construction of the two types of success and the attribution of characteristic features, university students behaved differently from working professionals. Just one example to illustrate this: graduates interpret and handle communicative skills and well-informedness in quite a different way and context than active professionals do. All things considered, however, one can say that the similarities in the behavior of the two subsamples are more marked than the differences. The consensual elements are decisive in shaping the image of success entertained by the intellectuals, irrespective of whether they are still preparing to engage in an occupation or are already exercising it.

The hypothesis that the personally known successful person is far more idealized than the general Hungarian person of success was clearly verified. This is not surprising in itself, since in social perception, and particularly in personal perception, there are typical differences in the assessments of a person who is closer to us, belongs to our group or our environment, and those at greater psychological distance from us or who belong to another group: we may evaluate them more schematically, or in a more differentiated way, depending on the challenges of the social situation. ${ }^{10}$

What is thought-provoking in our results is not the difference between the two types of images of success, but the emotionally negative attitudes to the general Hungarian person of success in both populations. As a reminder: the personally known successful person owed his success to his outstanding qualities, personal efforts, abilities and moral courage, while the success of the general Hungarian successful person can be attributed to external factors: being well-informed, having good connections, luck, etc. Our findings suggest that we consider a personally known successful person to be better than his fellows who are strangers to us, but probably fight in similar ways for success.

10 And it also depends on whether we pass judgment from the perspective of the actor or the observer. Jones and Nisbett (1971) pointed out that the 'actor' and the 'observer' adopt different perspectives when interpreting the causes of certain behavior. This phenomenon may apply to the assessment of successfulness. In our investigation, as noted, respondents evaluated both successful persons from the perspective of the 'observer'. 
Several psychological interpretations can be offered in explanation of this phenomenon. For several reasons, "psychological distance" seems to be the valid explanatory principle. First: even if the personally known successful person is a distant relative or acquaintance, the respondent has probably chosen them because they represent a sort of exemplary pattern; they are easier to identify with. Identification with the potential reference person itself creates a positive emotional attitude. The second effect, related directly to the first, is the following: we trust more anyone we in theory have the power to control or influence, even if we do not actually control or influence them: the visibility and potential of the situation is psychologically relevant and effective. Thirdly, the phenomenon that Tversky and Kahneman identified in another context in relation to the illusion of foreseeing the future is presumably a contributory factor to the evolution of the generalized image of the Hungarian successful person. The authors' thesis is that we judge on the basis of individual events, not on the average of events (Tversky, Kahneman, 1974). Our judgment of the Hungarian successful person is influenced, mostly through the mass media, by unique successes that stink of political ambition and/or ostentatious consumption and irritating levels of wealth.

It also underscores the generalized nature of success images adopted by society, or at least by the professionals we surveyed, that there were no truly profession-specific differences between the assessments. This is in spite of the fact that the respondents we chose were representatives of occupations widely differing as to their chances of success. The lack of profession-specific divergence confirms the assumption that social representations are not primarily tied to, or influenced by, social status, but rather to so-called collective ideologies. Some components of these may become positively or negatively prejudiced stereotypes and actualized in such fields as, e.g., success and failure. Underlying the choice of causes in individual explanations are "stereotypes and prejudices" that presuppose a chain of causes, similarly to the usual explanations of richness and poverty (Csepeli et al., 1992:23).

When listening to reason, those approving of modernization cannot deny the need for personal success, but - often somewhat inconsistently - they judge successful people negatively, suspiciously, especially in view of the means used to attain success.

How well this attitude is grounded is not the subject of this investigation, which encountered again the usual dilemma with attributional research: we cannot say whether the tendencies to add gloss to the personally known successful person and undervalue the general Hungarian person of success, especially in regard to their morals and intellectual capacity, are typical of the subject of judgment, or the person who judges. Probably the "mote-beam" mechanism (as Ichheiser called it), which is rooted in self-protection or self-rationalization, also plays a 
part: one pardons oneself, and at the same time enlarges every piece of negative information concerning the Other.

Our research findings agree remarkably well with the results of Hungarian research into social justice and equality of opportunity. They reveal that elements of the former egalitarian view are deeply rooted and act almost like stereotypes, not allowing ideas about the road to success to become coherent and inspiring. One reason may be that in poor Central European countries with weak democratic traditions the dynamism of the goals and norms of success is underlain by a different real space. Perhaps this weak image of success also feeds on an allegedly general "Hungarian specificity": orientation to failure (Csepeli, 1990). Why the above tendency more strongly characterizes those still at school than those already at work will be answered from the remainder of the investigation. Just as a reference, we can mention that the future the undergraduates imagine for themselves in relation to work and existence is pessimistic, whereas a fear of the future makes one uncertain and suspicious about otherness. ${ }^{11}$ Especially when this otherness refers to future existence, and the social macroclimate is such that the laws of "savage capitalism" make the conditions, possibilities and consequences of future behavior incalculable and incomprehensible.

\section{REFERENCES}

Bendix, R., Lipset, S.M. (Eds) 1953, Class, Status and Power. A Reader in Social Stratification. Glencoe, Ill.: Free Press.

Csepeli György, et al (1992) A gazdagság és a szegénység okairól adott magyarázatok rejtett normativ szempontjai Magyarországon [The hidden normative viewpoints of explanations given to clarify the causes of richness and poverty in Hungary] Szociológiai Szemle, 3.21-39.

Forgas, J., Morris, S., Furnham, A. (1982), Lay Explanation of Wealth: Attributions for Economic Success. Journal of Applied Sociological Psychology, 12, 381-397.

Hoppe, F. (1930), Erfolg und Miserfolg. Psychol. Forschung, 14, 1-62.

Hyman, H.H. (1953), The value system of different classes: A social psychological contribution to the analysis of stratification. In Bendix, R., Lipset, S.M. (Eds.), Class, Status and Power: A Reader in Social Stratification. Glencoe, Ill.: Free Press.

11 Why the above-analyzed tendency is more powerful among those still at school than among earning professionals may also be explained by the results of former research into the images of future, harmonizied with the findings of this survey (Vari-Szilagyi, 1992, Váriné Szilágyi, I., Solymosi Zs. 1995). 
Heider, F., (1958), The psychology of interpersonal relations. New York: Wiley. Hunyady György (1981), Cognitive complexity concerning judgments of persons and ideological topics. in: Pszichológia 1, 105-130.

Ichheiser, G. (1930), Kritik des Erfolges. Eine soziologische Untersuchung. Leipzig: Hirschfeld.

Ichheiser, G. (1933), Die Vieldeutigkeit in Begriff des Erfolges. In: Zeitschrift für paedagogische Psychologie und experimentelle Paedagogik, 34, 97-104.

Ichheiser, G. (1970), Appearance and Reality. San Francisco:Jossey-Bass.

Jones,E.E.,R.E.Nisbett(1971), The actor and the observer: Divergent perceptions of the causes of behavior. Journal of Experimental Social Psychology, 7: 319342.

Kahneman, D., Slovic, P., Tversky, A. (Eds.), Judgement under Uncertainty: Heuristics and Biases. New York:Cambridge University Press.

Katz, F.M. (1964), The Meaning of Success: Some Differences in Value Systems of Social Classes. The Journ. of Soc. Psychol. 62., 141-148.

Lengyel Gy.- Szántó Z. (2001), A gazdasági élet szociológiája. Budapest: Aula Kiadó.

Lewin, K. (1936), Principles of Topological Psychology. McGraw-Hill Book Company. New York.

Lewin, K., Dembo, T., Festinger, L., Sears, P. (1944), Level of aspiration. In: Hunt, J.Mc. (ed.) Handbook of Personality and the Behavior Disorder. The Ronald Press, N.Y.

Mannheim, K. (1930), Über das Wesen und die Bedeutung des wirtschaftlichen Erfolgsstrebens. in: Archiv für Sozialwissenschaft und Sozialpolitik, 63. In: Essays on the Sociology of Knowledge. London:1952. 230-276.

Merton, K. (1963/1968), Social Theory and Social Structure. Glencoe, Ill.: Free Press.

Moscovici, S. (1981), Social Representation. In: J.P.Forgas (Ed.) Social Cognition: Perspectives on everyday understanding. London, New York:Academic Press.

Tversky, A., Kahneman, D. (1974), Judgement under Uncertainty: Heuristics and Biases. Science, 185: 1124-1131.

Váriné Szilagyi I. (1990), Gustav Ichheiser a képességröl, a sikerről és az érvényesülésról (Gustav Ichheiser on ability, success and rise on the social ladder) Magyar Pszichológiai Szemle, 5-6, 203-224.

Váriné Szilágyi I. (1992) A jövő vonz vagy taszít? Remények és félelmek az értelmiségi pályára készülő́k jövőképében. (Future: Is it attractive or repelling? Hopes and fears in the images of the future among would-be professional). In: Társadalom és felsőoktatás, vol.2. (Ed. Solymosi Zsuzsa), A felsőoktatás fejlesztését szolgáló kutatások. Felsőoktatási Koordinációs Iroda, Budapest. $55-168$. 
Vari-Szilagyi, I. (2002) Ability and Adjustment to Work. A New Look on Ability: The Context beyond Traits. In: AGSÖ Archiv für die Geschichte der Soziologie in Österreich, Newsletter (Graz), Nr.23. 28-36.

Váriné Szilágyi, I., Solymosi Zs. (1995): A siker szociális reprezentációja értelmiségi rétegeknél. (Social representation of success in the Strata of Intellectuals). Szociológiai Szemle, 1995-1. 25-54.

Váriné Szilágyi I.-Solymosi Zs.(eds.)(1999), A siker lélektana (Psychology of success). Budapest, Új Mandátum Könyvkiadó.

Weber, M. (1930/1982) A protestáns etika és a kapitalizmus szelleme (The Protestant Ethic and the Spirit of Capitalism). Budapest, Gondolat Kiadó.

\section{Appendix No.1}

Subsample of university students $(\mathrm{N}=198)$ Order of importance of factors contributing to success

\section{A) Personally known successful person}

Rank/Name of the factor

1. Hard work

2. Decision-making ability

3. Determined manner

4. Being well-informed

5. Perseverance

6. Glib tongue

7. Outstanding intellectual capacities

8. Outstanding achievements

9. Insight into character

10. Good connections

11. Firm morality

\section{Mean ST.D.} 3.347

3.312

3.239

3.177

3.176

3.192

0.76

0.77

0.80

0.85

0.80

0.86

2.979

2.948

2.819

2.715

2.707

0.85

0.84

0.86

0.98

0.99
12. Attractive appearance

13. Luck

14. Favorable financial state

2.516

2.281

1.943

B) Generalized Hungarian successful person

Rank/name of factor

1. Being well-informed

2. Good connections

3. Decision-making ability

4. Determined manners

5. Good faculty of speech

6. Favorable financial state

7. Luck, chance

8. Insight into character

9. Perseverance, diligence

10. Hard work

Mean ST.D

3.521

0.74

3.518

0.70

3.404

0.68

3.375

0.68

3.368

0.76

3.150

0.83

3.094

0.79

$2.881 \quad 0.84$

$2.632 \quad 0.76$

11. Good intellect. capacities

2.622

0.78

12. Outstanding achievement

2.593

0.76

13. Appealing looks

0.81

14. Firm morality

0.76

Appendix No.2

1. Decision-making ability

3.458

0.704

2. Being well-informed

3.364

0.782

Subsample of professionals $(\mathrm{N}=110)$

3. Determined manners

3.321

0.737

Order of importance of factors contributing

4. Hard work

3.208

0.836 to success

5. Glib tongue

3.298

0.877

6. Perseverance

3.190

0.889

A) Personally known successful person

7. Good connections

3.038

0.955

Rank/name of factor

Mean ST.D

8. Insight into character

2.896

0.804 


\begin{tabular}{|c|c|c|c|c|c|}
\hline 9. Outstanding intellectual & & & 3. Decision-making ability & 3.390 & 0.740 \\
\hline capacities & 2.877 & 0.912 & 4. Determined manners & 3.314 & 0.670 \\
\hline 10. Outstanding achievement & 2.774 & 0.979 & 5. Favorable financial stand & 3.198 & 0.810 \\
\hline 11. Attractive appearance & 2.538 & 0.886 & 6. Glib tongue & 3.189 & 0.757 \\
\hline 12. Firm morality & 2.528 & 0.978 & 7. Insight into character & 2.991 & 0.775 \\
\hline 13. Luck & 2.390 & 0.956 & 8. Luck/chance & 2.962 & 0.755 \\
\hline 14. Favorable financial stand. & 2.330 & 1.002 & 9. Perseverance & 2.745 & 0.757 \\
\hline & & & 10. Hard work & 2.667 & 0.816 \\
\hline B) Generalized Hungarian & uccessfi & person & 11. Outstanding achievement & 2.651 & 0.805 \\
\hline Rank / name of factor & Mean & ST.D & 12. Outstanding brains & 2.604 & 0.902 \\
\hline 1.Good connections & 3.585 & 0.599 & 13. Appealing looks & 2.452 & 0.806 \\
\hline 2. Being well-informed & 3.524 & 0.622 & 14. Firm morality & 1.953 & 0.855 \\
\hline
\end{tabular}

\section{Appendix No.3}

\section{Subsample of students $(\mathrm{N}=198)$}

Ranking of characteristics

\section{A) Personally known successful person}

Rank/Variable

1. active

2. self-reliant

3. self-assured

4. ambitious

5. determined

6. energetic

7. reliable

8. clever

9. sympathetic

10. acknowledged

11. positive

12. demanding

13. flexible

14. helpful

15. good

16. merry

17. quick

18. optimistic

19. strong

20. risk-taking
- passive

- lacking self-reliance

- shy

- lacking ambitions

- uncertain

- enervated

- unreliable

- stupid

- antipathetic

- unacknowledged

- negative

- undemanding

- rigid

- unhelpful

- bad

- sad

- slow

- weak

- refusing to take risks
- pessimistic
21. generous

22. independent

23. adapting

24. selfless

25. economical

B) Generalized Hungarian successful person

$\begin{array}{ll}\text { 1. active } & \text { - passive } \\ \text { 2. self-assured } & \text { - shy } \\ \text { 3. determined } & \text { - uncertain } \\ \text { 4. ambitious } & \text { - lacking ambitions } \\ \text { 5. energetic } & \text { - enervated } \\ \text { 6. self-reliant } & \text { - lacking self-reliance } \\ \text { 7. flexible } & \text { - inflexible } \\ \text { 8. risk-taking } & \text { - taking no risks } \\ \text { 9. acknowledged } & \text { - unacknowledged } \\ \text { 10. quick } & \text { - slow } \\ \text { 11. strong } & \text { - weak } \\ \text { 12. reliable } & \text { - unreliable } \\ \text { 13. clever } & \text { - stupid } \\ \text { 14. optimistic } & \text { - pessimistic } \\ \text { 15. demanding } & \text { - undemanding } \\ \text { 16. adapting } & \text { - not adapting } \\ \text { 17. positive } & \text { - negative } \\ \text { 18. independent } & \text { - dependent } \\ \text { 19. merry } & \text { - sad }\end{array}$

- petty

- dependent

- not adapting

- selfish

- squandering 


$\begin{array}{llll}\text { 20. sympathetic } & \text { - antipathetic } & \text { 23. economical } & \text { - squandering } \\ \text { 21. generous } & \text { - petty } & \text { 24. helpful } & \text { - unhelpful } \\ \text { 22. good } & \text { - bad } & \text { 25. selfless } & \text { - selfish }\end{array}$

\section{Appendix No.4}

\section{Subsample of professionals $(\mathrm{N}=107)$}

\section{Ranking of characteristics}

\section{A) Personally known successful person}

Rank / Variable

1. ambitious

2. self-reliant

3. active

4. determined

5. energetic

6. self-assured

7. clever

8. demanding

9. quick

10. acknowledged

11. reliable

12. strong

13. flexible

14. independent

15. optimistic

16. positive

17. risk-taking

18. merry

19. sympathetic

20. adapting

21. generous

22. helpful

23. good
- lacking ambitions

- lacking self-reliance

- passive

- uncertain

- enervated

- timid

- stupid

- undemanding

- slow

- unacknowledged

- unreliable

- weak

- rigid

- dependent

- pessimistic

- negative

- taking no risks

- sad

- antipathetic

- not adapting

- petty

- unhelpful

- bad
24. economical

25. selfless

B) generalized Hungarian successful person

1. active

2. self-assured

3. determined

4. ambitious

5. energetic

6. self-reliant

7. flexible

8. risk-taking

9. acknowledged

10. quick

11. strong

12. reliable

13. clever

14. optimistic

15. demanding

16. adapting

17. positive

18. independent

19. cheerful

20 . sympathetic

21. generous

22. good

23. economical

24. helpful

25. selfless
- squandering

- selfish
- passive

- timid

- uncertain

- lacking ambitions

- enervated

- lacking self-reliance

- inflexible

- taking no risks

- unacknowledged

- slow

- weak

- unreliable

- stupid

- pessimistic

- undemanding

- not adapting

- negative

- dependent

- sad

- antipathetic

- petty-minded

- bad

- squandering

- unhelpful

- selfish 